\title{
SUSCEPTIBILITY OF SOME EGYPTIAN LEGUME VARIETIES TO THE INFESTATION WITH THE COWPEA BEETLE, Callosobruchus maculatus (F.) (COLEOPTERA: BRUCHIDAE).

\author{
Mahmoud, M.A.*; A. I. A. Farghal ${ }^{* *}$; Y. M. Omar* and \\ R. E. Hassan* \\ *Plant Protection Dept., Fac. Agric., Al-Azhar Univ., Egypt \\ ** Plant Protection Dept., Fac. Agric., Assiut Univ., Egypt
}

\begin{abstract}
The present investigation is carried out to evaluate the relative susceptibility of eight legume varieties to the infestation with the cowpea beetle, Callosobruchus maculatus (F.). The loss in grain weight and the percentage of infested grains were determined in choice and force infestation tests. The obtained results, either in the choice or non-choice infestation tests, indicated that, none of the tested varieties were completely resistant against the attack by the pest but their susceptibility to the infestation varied considerably. Regardless of legume variety, cowpea varieties showed high susceptibility to the infestation by $C$. maculatus. While, faba bean and lentil varieties were the least ones and chickpea varieties were found to be inbetween. Cowpea variety (Dokki 331) was the most susceptible variety resulted in an average infestation level of $90.33 \%$, and a maximum weight loss of $15.29 \mathrm{~g} / 100 \mathrm{~g}$ seeds. However, lentil variety (Giza 370) was the least susceptible one with an average infestation level of $2.33 \%$, and a minimum weight loss of $2.99 \mathrm{~g} / 100 \mathrm{~g}$. seeds. A significant positive correlation was found between the infestation of grains and weight loss $\left(r=0.94^{* *}-0.98^{\star *}\right)$.

Keywords: Stored grain pests, legume varieties, Callosobruchus maculatus, susceptibility.
\end{abstract}

\section{INTRODUCTION}

Cowpea (Vigna unguiculata (L.) Walp), (Leguminosae: Papilionidae) has been described as the most important legume crop and a major source of dietary protein in the tropical and subtropical regions of the world (Ofuya, 1986; Oparake et al., 1998).

Efforts to maximize production by farmers are often hampered by diseases and insect attack. In seed storage, the main problem is the infestation by a major insect species, the bruchid beetle, Callosobruchus maculatus (F.) (Jackai and Daoust, 1986). It starts the infestation in the field, but a heavy damage is done in storage (Swella and Mushobozy, 2007). The estimated losses due to this pest in various pulses ranged from $30-40 \%$ within a period of six months, and the post harvest seed losses can reach even $100 \%$ during severe periods of infestation (Mahendra and Mohan, 2002).

Some physical and chemical characteristics of legume pods and seeds have been identified as influencing resistance to insects; include pod thickness and hardness, seed coat thickness and hardness, as well as chemical compositions of seed (Fatunla and Badaru, 1983 and Silim Nahdy, 1995). 
Knowledge of the host-pest relationship and the environment interaction is an important prerequisite when devising a cost- effective pest management package. For C. maculatus, it is important to know its host range. So that storage planning can be made to avoid cross- infestation among susceptible legume seeds species when stored in one place. This will prevent heavy build-up of C. maculatus populations.

Therefore, this study was carried out to determine the susceptibility of seeds of eight legumes to the infestation by $C$. maculatus in choice and nonchoice experiments.

\section{MATERIALS AND METHODS}

In order to study the susceptibility of some legume varieties to the cowpea beetle, C. maculatus. Legume seeds were firstly sieved to remove stones, dust, insects ... etc, and then frozen for 7 days to eliminate mites and insects. The seed was tempered 2 weeks at $27 \pm 2^{\circ} \mathrm{C}$ and $70 \pm 5 \%$ R.H. (Russell and Cogburn, 1977). The tested legume varieties were: Two varieties of chickpea (Giza195 and Giza 531); two varieties of cowpea (Dokki 331 and Karim 7); two varieties of faba bean (Giza 843 and Masr 1) and two varieties of lentil (Giza 9 and Giza 370). These varieties were obtained from Egyptian National Research Center. Two experiments were done, the first one was a choice infestation test and the second was non-choice or force infestation test.

\section{a- Choice infestation test:-}

To study the susceptibility of different legume seeds to the infestation with cowpea beetle, C. maculatus, the standard weight of the samples was 100 grams. Three samples of each variety were counted and weighted on an analytical balance accurate to $0.01 \mathrm{~g}$ and each sample was kept in plastic container $(8 \mathrm{~cm}$. height and $4.5 \mathrm{~cm}$. diameter). These containers ( 3 samples $x 8$ varieties $=24$ containers $)$ were placed in a wooden box $(60 \times 60 \times 8 \mathrm{~cm}$. $)$. Batches of about 240 couple adult cowpea beetles were released into the box. All samples were kept under laboratory conditions. Samples were examined at the end of each generation. The experiment has been continued for two generations. After each generation, the insects had been removed the seeds in each container were checked and reweighted to determine the infestation or damaged seed and weight loss.

\section{Percent of damaged seeds:-}

Total number of seeds per sample was counted. Seeds showing pest damage were also separated and counted. The percentage of infested seeds was calculated as follows:

\section{Weight loss:-}

$$
\text { Damaged seeds }(\%)=\frac{\text { No. } \text { damaged seeds }}{\text { Total no. seeds }} \times 100
$$

Weight loss was determined since the introduction of insects with the seed of legume for each variety until adult emergence of the F1 and F2 generations. According to the equation of Mebarkia et al. (2010) used to calculate the loss in seeds: 
Where,

$$
\mathbf{W L}=\mathbf{W h}-\mathbf{W d}
$$

$$
\mathrm{WL}=\text { Weight loss. }
$$

Wh $=$ Weight healthy seeds before infestation

Wd $=$ Weight damaged seeds after infestation.

b- Non- choice infestation test:-

Adults of $C$. maculatus were collected from a mass rearing under experimental conditions of temperature $27 \pm 2^{\circ} \mathrm{C}$ and $70 \pm 5 \%$ relative humidity. In each box, 20 adults of $C$. maculatus were placed on $100 \mathrm{~g}$ seeds for each variety. Each sample was kept in a plastic container $(8 \mathrm{~cm}$. height and 4.5 $\mathrm{cm}$. diameter) and allowed to lay eggs for 7 days, then removed. The jars were covered with muslin and held in place with rubber bands, then kept until the new adults started to emerge. The experiment was continued under laboratory conditions until the emergence of cowpea beetle adults stopped. This experiment was also continued for two generations. Percentage of infested seeds and weight loss in seeds were calculated.

\section{RESULTS AND DISCUSSION}

\section{Choice-infestation test:}

Data (Table 1) show the percentages of the damaged seeds and the progressive loss in weight of each legume variety caused by the cowpea beetle after the first generation. All varieties had some degree of infestation by the pest. On the base of percentage of damaged seeds, the two varieties of lentil (Giza 370 and Giza 9) were found to be the least susceptible, whereas the two varieties of cowpea were the highest susceptible ones.

On the other side, when these varieties were arranged according to the weight loss, it is clear that the lentil varieties (Giza 370 and Giza 9) were the least damaged, whereas, cowpea varieties (Karim 7 and Dokki 331) were the highest one. There is a significant positive correlation between the percentage of damaged grains and the weight loss $\left(r=0.98^{* *}\right)$. After two generations, infestation percentage and loss values seemed to be greater than those recorded after the first generation (Table2). A significant positive correlation was also recorded between the number of damaged seeds and the weight loss $\left(r=0.97^{\star *}\right)$.

According to both parameters, lentil variety (Giza 370) was the least susceptible and damaged variety (with an infestation percentage of $2.33 \%$ and a loss of $2.99 \mathrm{~g} / 100 \mathrm{~g}$ of seeds), whereas the cowpea variety (Dokki 331 ) was the highest susceptible one (with an infestation level of $90.33 \%$ and a loss of $15.29 \mathrm{~g} / 100 \mathrm{~g}$ of seed). 
Table (1): Susceptibility of some Egyptian legume varieties to the infestation with $C$. maculatus - in a choice infestation test, after the first generation.

\begin{tabular}{|l|c|c|c|}
\hline \multirow{2}{*}{ Legume varieties } & \multicolumn{2}{|c|}{ Mean \pm SE } \\
\cline { 3 - 4 } \multicolumn{2}{|c|}{} & \% Infestation & $\begin{array}{c}\text { Weight loss } \\
(\mathbf{g} / \mathbf{1 0 0 g})\end{array}$ \\
\hline \multirow{2}{*}{ Chickpea } & Giza 195 & $17.0 \pm 2.00 \mathrm{c}$ & $2.54 \pm 0.30 \mathrm{~cd}$ \\
\cline { 2 - 4 } & Giza 531 & $24.67 \pm 2.33 \mathrm{~b}$ & $2.85 \pm 0.07 \mathrm{c}$ \\
\hline \multirow{2}{*}{ Cowpea } & Dokki 331 & $72.67 \pm 3.18 \mathrm{a}$ & $7.88 \pm 0.18 \mathrm{a}$ \\
\cline { 2 - 4 } & Karim 7 & $30.33 \pm 2.67 \mathrm{~b}$ & $4.17 \pm 0.16 \mathrm{~b}$ \\
\hline \multirow{2}{*}{ Faba bean } & Giza 843 & $3.00 \pm 1.15 \mathrm{e}$ & $1.94 \pm 0.17 \mathrm{e}$ \\
\cline { 2 - 4 } & Masr 1 & $9.33 \pm 0.88 \mathrm{~d}$ & $2.02 \pm 0.31 \mathrm{de}$ \\
\hline \multirow{2}{*}{ Lentil } & Giza 9 & $1.66 \pm 0.66 \mathrm{e}$ & $1.69 \pm 0.09 \mathrm{e}$ \\
\cline { 2 - 4 } & Giza 370 & $1.00 \pm 0.57 \mathrm{e}$ & $1.50 \pm 0.05 \mathrm{e}$ \\
\hline
\end{tabular}

Means in the same column followed by the same letter are not significantly different.

Table( 2 ): Susceptibility of some Egyptian legume varieties to the infestation with C. maculatus - in a choice infestation test, after the second generation.

\begin{tabular}{|l|c|c|c|}
\hline \multirow{2}{*}{ Legume varieties } & \multicolumn{2}{|c|}{ Mean \pm SE } \\
\cline { 3 - 4 } \multicolumn{2}{|c|}{} & \% Infestation & $\begin{array}{c}\text { Weight loss } \\
(\mathbf{g} / 100 \mathrm{~g})\end{array}$ \\
\hline \multirow{2}{*}{ Chickpea } & Giza 195 & $36.67 \pm 0.66 \mathrm{~d}$ & $5.52 \pm 0.33 \mathrm{c}$ \\
\cline { 2 - 4 } & Giza 531 & $41.33 \pm 1.33 \mathrm{c}$ & $5.94 \pm 0.15 \mathrm{c}$ \\
\hline \multirow{2}{*}{ Cowpea } & Dokki 331 & $90.33 \pm 2.03 \mathrm{a}$ & $15.29 \pm 0.21 \mathrm{a}$ \\
\cline { 2 - 4 } & Karim 7 & $61.33 \pm 0.88 \mathrm{~b}$ & $10.07 \pm 0.04 \mathrm{~b}$ \\
\hline \multirow{2}{*}{ Faba bean } & Giza 843 & $11.00 \pm 1.73 \mathrm{f}$ & $3.76 \pm 0.07 \mathrm{e}$ \\
\cline { 2 - 4 } & Masr 1 & $24.0 \pm 1.15 \mathrm{e}$ & $4.55 \pm 0.12 \mathrm{~d}$ \\
\hline \multirow{2}{*}{ Lentil } & Giza 9 & $5.66 \pm 1.20 \mathrm{~g}$ & $3.17 \pm 0.01 \mathrm{f}$ \\
\cline { 2 - 4 } & Giza 370 & $2.33 \pm 0.88 \mathrm{~g}$ & $2.99 \pm 0.03 \mathrm{f}$ \\
\hline
\end{tabular}

Means in the same column followed by the same letter are not significantly different.

Non- choice (force) infestation test:

Data (Table 3) show the relative susceptibility of the eight chosen legume varieties to the infestation with the cowpea beetle after the first generation. It is clear that, the larvae completed their development inside all tested legume varieties. In respect to the percentages of infestation, there were clear significant differences between some varieties. According to the weight loss, the adult had not caused loss greater than $2.75 \mathrm{~g} / 100 \mathrm{~g}$ of seeds. Lentil variety (Giza 370 ) appeared to be the least damaged variety with an average weight loss of $0.39 \mathrm{~g} / 100 \mathrm{~g}$. and the cowpea variety (Dokki 331) was the most damaged variety with an average weight loss of $2.75 \mathrm{~g} / 100 \mathrm{~g}$. There was a significant positive correlation between the number of damaged grains and weight loss $\left(r=0.94^{\star *}\right)$.

After two generations, the cowpea beetle was damaging some varieties more severely than others. As shown in (Table 4) lentil variety (Giza 370 ) was the least susceptible variety to the pest with an infestation level of $1.66 \%$ and weight loss $2.14 \mathrm{~g} / 100 \mathrm{~g}$. On the other hand, cowpea variety (Dokki 331 ) was the most susceptible one with a maximum infestation level of $65.67 \%$ and weight loss of $7.62 \mathrm{~g} / 100 \mathrm{~g}$. A significant positive correlation was also observed between the number of damaged seeds and weight loss $\left(r=0.96{ }^{* *}\right)$. 
Table( 3): Susceptibility of some Egyptian legume varieties to the infestation with $C$. maculatus - in a non-choice infestation test, after the first generation.

\begin{tabular}{|l|c|c|c|}
\hline \multirow{2}{*}{ Legume varieties } & \multicolumn{2}{|c|}{ Mean \pm SE } \\
\cline { 3 - 4 } \multicolumn{2}{|l|}{} & \% Infestation & $\begin{array}{c}\text { Weight loss } \\
(\mathbf{g} / \mathbf{1 0 0 g})\end{array}$ \\
\hline \multirow{2}{*}{ Chickpea } & Giza 195 & $7.66 \pm 2.03 \mathrm{c}$ & $1.46 \pm 0.15 \mathrm{c}$ \\
\cline { 2 - 4 } & Giza 531 & $14.33 \pm 3.33 \mathrm{~b}$ & $2.04 \pm 0.13 \mathrm{~b}$ \\
\hline \multirow{2}{*}{ Cowpea } & Dokki 331 & $27.33 \pm 0.66 \mathrm{a}$ & $2.75 \pm 0.08 \mathrm{a}$ \\
\cline { 2 - 4 } & Karim 7 & $13.0 \pm 1.00 \mathrm{~b}$ & $2.20 \pm .019 \mathrm{~b}$ \\
\hline \multirow{2}{*}{ Faba bean } & Giza 843 & $1.66 \pm 0.33 \mathrm{de}$ & $0.72 \pm 0.16 \mathrm{de}$ \\
\cline { 2 - 4 } & Masr 1 & $5.33 \pm 0.66 \mathrm{~cd}$ & $0.85 \pm 0.08 \mathrm{~d}$ \\
\hline \multirow{2}{*}{ Lentil } & Giza 9 & $0.66 \pm 0.33 \mathrm{e}$ & $0.68 \pm 0.16 \mathrm{de}$ \\
\cline { 2 - 4 } & Giza 370 & $0.33 \pm 0.33 \mathrm{e}$ & $0.39 \pm 0.07 \mathrm{e}$ \\
\hline
\end{tabular}

Means in the same column followed by the same letter are not significantly different.

It could be generally concluded that, cowpea variety (Dokki 331) was the most susceptible legume variety to the cowpea beetle and if stored in an area scattered with this pest, the variety can be heavily damaged by this scourge. In contrary, lentil variety (Giza 370 ) was the least susceptible variety. The rest of legume varieties as indicated in Tables 2 and 4 appeared to be moderately susceptible legume varieties.

Table( 4 ): Susceptibility of some Egyptian legume varieties to the infestation with $C$. maculatus - in a non- choice infestation test, after the second generation.

\begin{tabular}{|c|c|c|c|}
\hline \multirow{2}{*}{\multicolumn{2}{|c|}{ Legume varieties }} & \multicolumn{2}{|c|}{ Mean \pm SE } \\
\hline & & \multirow{2}{*}{$\begin{array}{c}\% \text { Infestation } \\
12.33 \pm 1.45 \mathrm{~d}\end{array}$} & \multirow{2}{*}{$\begin{array}{c}\begin{array}{c}\text { Weight loss } \\
\text { (g/100g) }\end{array} \\
4.51 \pm 0.08 \mathrm{c}\end{array}$} \\
\hline & Giza 195 & & \\
\hline Chickpea & Giza 531 & $27.67 \pm 1.76 \mathrm{c}$ & $4.69 \pm 0.09 c$ \\
\hline \multirow{2}{*}{ Cowpea } & Dokki 331 & $65.67 \pm 1.45 \mathrm{a}$ & $7.62 \pm 0.15 a$ \\
\hline & Karim 7 & $49.0 \pm 2.31 \mathrm{~b}$ & $5.52 \pm .0 .08 b$ \\
\hline \multirow[t]{2}{*}{ Faba bean } & Giza 843 & $3.33 \pm 0.88 \mathrm{e}$ & $3.13 \pm 0.15 \mathrm{e}$ \\
\hline & Masr 1 & $14.67 \pm 1.33 \mathrm{~d}$ & $3.50 \pm 0.15 d$ \\
\hline \multirow{2}{*}{ Lentil } & Giza 9 & $2.66 \pm 0.88 \mathrm{e}$ & $2.87 \pm 0.03 \mathrm{e}$ \\
\hline & Giza 370 & $1.66 \pm 0.33 \mathrm{e}$ & $2.14 \pm 0.04 f$ \\
\hline
\end{tabular}

Means in the same column followed by the same letter are not significantly different.

To endorse the previous obtained results, the proteins, carbohydrates and moisture content were assessed in the tested varieties as shown in Table 5. The statistical analysis shows the presence significant difference between all tested varieties in the triple checked characters. Lentil variety (Giza 370) has the least content of proteins $(23.18 \%)$, moisture $(7.85 \%)$, and the highest content of carbohydrates $(59.12 \%)$. These results explain the resistance of this variety. While in cowpea variety (Dokki 331) resulted in increased proteins content (29.84\%) increased its susceptibility to the pest.

The relationship between proteins, moisture content, carbohydrates and infestation and loss percentages were statistically analyzed in both tests (choice and non-choice tests) and for both generations; the correlation values ranged from $\left(0.88^{\star \star}-0.70^{\star}\right) ;\left(-0.83^{\star \star}-0.56\right)$ and $\left(-0.92^{\star \star}--0.80^{\star \star}\right)$, respectively. 
Table (5): Percentage of protein, carbohydrate and moisture contents in legume varieties.

\begin{tabular}{|l|c|c|c|c|}
\hline \multirow{2}{*}{ Legume varieties } & \multicolumn{3}{|c|}{ Mean \pm SE } \\
\cline { 3 - 5 } & $\begin{array}{c}\% \\
\text { Protein }\end{array}$ & $\begin{array}{c}\% \\
\text { Carbohydrate }\end{array}$ & $\begin{array}{c}\% \\
\text { Moisture }\end{array}$ \\
\hline \multirow{2}{*}{ Chickpea } & Giza 195 & $23.62 \pm 0.44 \mathrm{c}$ & $57.64 \pm 0.25 \mathrm{bc}$ & $6.95 \pm 0.18 \mathrm{c}$ \\
\cline { 2 - 5 } & Giza 531 & $23.84 \pm 0.66 \mathrm{bc}$ & $57.30 \pm 0.29 \mathrm{c}$ & $6.91 \pm 0.01 \mathrm{c}$ \\
\hline \multirow{2}{*}{ Cowpea } & Dokki 331 & $29.84 \pm 0.72 \mathrm{a}$ & $53.15 \pm 0.17 \mathrm{f}$ & $7.06 \pm 0.02 \mathrm{c}$ \\
\cline { 2 - 5 } & Karim 7 & $28.09 \pm 0.59 \mathrm{a}$ & $54.93 \pm 0.21 \mathrm{e}$ & $7.23 \pm 0.21 \mathrm{bc}$ \\
\hline \multirow{2}{*}{ Faba bean } & Giza 843 & $24.94 \pm 0.51 \mathrm{bc}$ & $57.23 \pm 0.12 \mathrm{c}$ & $7.57 \pm 0.23 \mathrm{ab}$ \\
\cline { 2 - 5 } & Masr 1 & $24.33 \pm 0.34 \mathrm{bc}$ & $56.04 \pm 0.14 \mathrm{~d}$ & $7.62 \pm 0.05 \mathrm{a}$ \\
\hline \multirow{2}{*}{ Lentil } & Giza 9 & $25.66 \pm 0.15 \mathrm{~b}$ & $58.21 \pm 0.22 \mathrm{~b}$ & $7.89 \pm 0.02 \mathrm{a}$ \\
\cline { 2 - 5 } & Giza 370 & $23.18 \pm 0.92 \mathrm{c}$ & $59.12 \pm 0.31 \mathrm{a}$ & $7.85 \pm 0.03 \mathrm{a}$ \\
\hline
\end{tabular}

Means in the same column followed by the same letter are not significantly different.

As indicated above, the values and trends of correlation coefficients give more supports to the obtained results in this study.

In agreement with the present findings, Swella and Mushobozy (2009) found that seeds of cowpea was the most susceptible and suitable legume seed for $C$. maculatus, whereas chickpea seeds were less susceptible. They advised farmers not to store cowpea, garden pea and pigeon pea seeds in the same place and / or at the same time in order to avoid cross infestation because of their high susceptibility to the pest. The highest susceptibility of cowpea seeds to the infestation by C. maculatus was reported by many authors, Adam and Baidoo (2008) stated that cowpea seeds possess certain characteristics such as the nature and hardness of the seed coat that makes them suitable for oviposion by $C$. maculatus. In general, varieties with smooth seed surface are preferred for oviposion as compared with wrinkled varieties that have a rough seed surface (Patil and Jadhav, 1985; Obeng-Ofori and Dankwah, 2002). Also, hardness of the seeds is due to the chemical composition of seed coat, which has an effect on the ability of $C$. maculatus to invade the seed (Friends, 1981 and Asiedu et al., 2000).

The chemical compounds found in the seed coat of leguminous plants include tannins, lignin, non-tannins and polyphenolic compounds, and their concentration may differ depending on the level of color pigmentation in the seed coat. Lignin has the function of cementing and anchoring cellulose fiber together, and give a mechanical rigidity to plants and also protects them against chemical, Physical and biological deteriorations. Moreover, Sarwar (2012) found a tolerant genotype of chickpea exhibited a hard and wrinkled seed coat, a dark brown color and a small size grain. These characteristics demonstrated a significant harmful effect to the pest appearance and reduced grain damage.

The present study demonstrates that, there is a variation between legume seeds in the term of susceptibility. Wholly, in agreement with the findings obtained by Singh and Singh (1990); Edde and Amatobi, (2003) and Maina et al., (2012).

From the abovementioned, the authors can derive that, the differences in biochemical constituents and hardness among the tested varieties of legume that will allow or prevent the pest and may act as 
repellents and/or biochemical inhibitors. The obtained results entail that, stored seed managers should be aware of potential differences in susceptibility of legume varieties to $C$. maculatus infestation to be easy to choose and use the right legume variety.

\section{REFERENCES}

Adam, J. I. and Baidoo, P. K. (2008). Susceptibility of five cowpea (Vigna unguiculata) varieties to attack by Callosobruchus maculatus ( $\mathrm{F}$.) (Coleoptera: Bruchidae). J. Ghana Sci., Association, 10: 85- 92.

Asiedu, E. A.; Powell, A. A. and Stuchbury, T. (2000). cowpea seed coat chemical analysis in relation to storage seed quality. Afric. Crop Sci. J., 8 (3): 283-284.

Edde, P. A. and Amatobi, C. I. (2003). Seed coat has no value in protecting cowpea seed against attack by Callosobruchus maculatus (F.). J. Stored Prod. Res., 39: 1-10.

Fatunla, J. and Badaru, K. (1983). Resistance of cowpea pods to Callosobruchus maculatus (F.). J. Agric. Sci. Camb., 100: 205-209.

Friends, J. (1981). plant phenolics, lignifications and plant diseases. Progress in Phytochem., 7: 197-261.

Jackai, L. E. N. and Daoust, R. (1986). Insect pests of cowpeas. Ann. Rev. Entomol., 31: 95-119.

Mahendra, K. and Mohan, S. (2002). Technology adaptation, estimation of loss and farmers behaviour in pulses storage. A study in Western Tamil Nadu Pestology, 26: 35-38.

Maina, Y. T.; Mbaya, A. M. and Mailafiya, D. M. (2012). Susceptibility of six local and four improved cowpea cultivars to Callosobruchus maculatus (F.) (Coleoptera: Bruchidae) infestation in north eastern Nigeria. J. Environ. Agric., in Developing Countries 4 (1): 31-37.

Mebarkia, A.; Rahbé, Y.; Guechi, A.; Bouras, A. and Makhlouf, M. (2010). Susceptibility of twelve soft wheat varieties, Triticum aestivum to Sitophilus granarius (L.) (Coleoptera: Curculionidae). Agric. and boil. J. N. Am. 1 (14): 571-578.

Obeng-Ofori, D. and Dankwah, J. A. (2002). Biological effect of four protestants applied to stored Bambara Groundnut against infestation by Callosobruchus maculatus (F.) (Coleoptra: Bruchidae). J. Ghana Sci. Associ., 42 (2): 41-51.

Ofuya, T. I. (1986). Use of wood ash, dry chill-pepper fruits and onion scale leaves for reducing Callosobruchus maculatus (F.) damage in cowpea seeds during storage. J. Agric. Sci. Camb., 107: 467-468.

Oparake, A.M.; Dike, M. C. and Onu, I. (1998). Evaluation of seed and leaf powder of neem (Azadirachta indica A. Juss) and pirimiphos-methyl for control of Callosobruchus maculatus (F.) in stored cowpea. Entomol. Soci., Nigeria. Occasional publ., 31: 237-242.

Patil, S. M. and Jadhav, L. D. (1985). Studies on the relative susceptibility of some promising varieties of pea, Pisum sativum to pulse beetle, Callosobruchus maculatus (F.) in storage. Bull. Grain Technnol., 20: 48. 
Russell, M. P. and Cogburn, R. R. (1977). World collection rice varieties: Resistance to seed penetration by Sitotroga cerealella (Oliver) (Lepidoptera: Gelechiidae). J. Stored Prod. Res., 13: 103-106.

Sarwar, M. (2012). Assessment of resistance to the attack of bean beetle, Callosobruchus maculatus (F.) in chickpea genotypes on the basis of various parameters during storage. Songklanakarin J. Sci. Technol., 34 (3): 287-291.

Silim Nahdy, M. (1995). Biotic and abiotic factors influencing the biology and distribution of common storage pests of pigeon pea, Ph.D. thesis Univ., Reading, UK.

Singh, B. B. and Singh, S. R. (1990). Preeding for bruchid resistance in cowpea. Pages 219-228. In "Bruchids and Legumes: Economics, Ecology and Coevolution". (Fuji, K.; Gatehouse, A. M. R.; Johnson, C. D.; Mitchel R. and eds Yoshida). Kluwear Acad. Publ., Netherlands.

Swella, B. G. and Mushobozy, D. M. K. (2007). Evaluation of the efficacy of protectants against cowpea bruchids, Callosobruchus maculatus (F.) on cowpea seeds (Vigna unguiculata (L.) Walp.). Plant Prot. Sci., 43: 68-72.

Swella, G. B. and Mushobozy, D. M. K. (2009). Comparative susceptibility of different legume seeds to infestation by cowpea bruchid, Callosobruchus maculatus (F.) (Coleoptera: Bruchidae). Plant Prot. Sci., 45(1): 19-24.

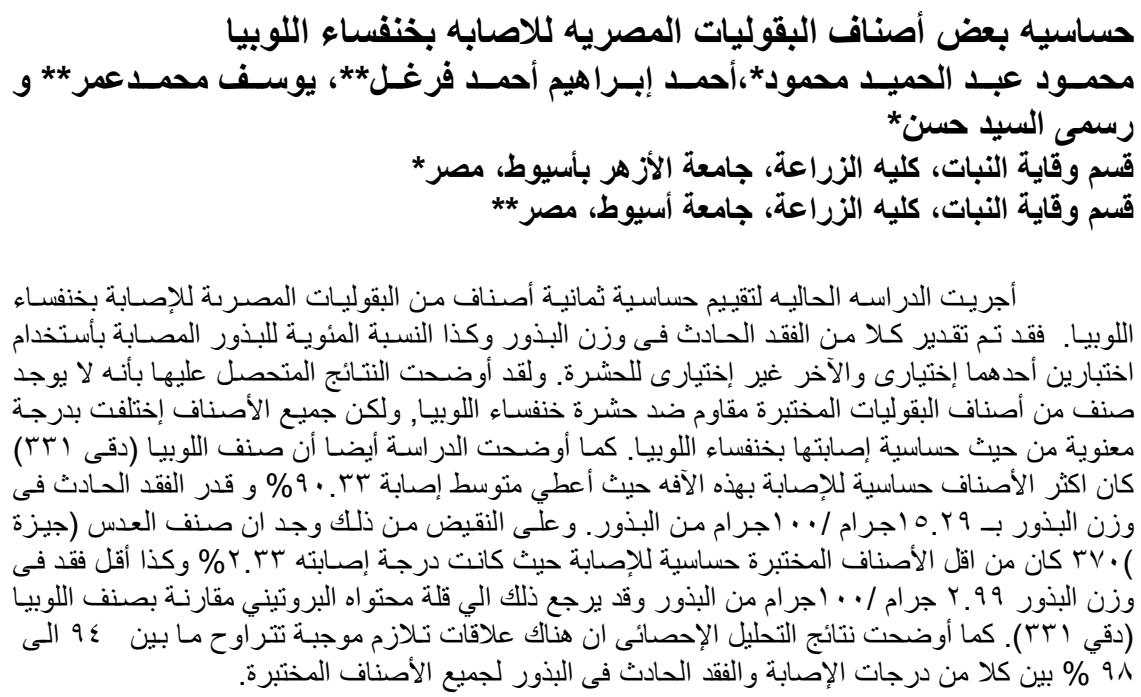

